\title{
Current Situation, Management Policy and Effects of Cross-Border Capital Flow in China
}

\author{
Wen Liu ${ }^{1,2}$ \\ ${ }^{1}$ Postdoctoral Workstation, China Construction Bank, Beijing, China \\ ${ }^{2}$ Postdoctoral Research Station, Tsinghua University, Beijing, China \\ Email: 386476940@qq.com
}

How to cite this paper: Liu, W. (2020). Current Situation, Management Policy and Effects of Cross-Border Capital Flow in China. Open Journal of Business and Management, $8,1103-1112$. https://doi.org/10.4236/ojbm.2020.83070

Received: April 4, 2020

Accepted: May 3, 2020

Published: May 6, 2020

Copyright (c) 2020 by author(s) and Scientific Research Publishing Inc. This work is licensed under the Creative Commons Attribution International License (CC BY 4.0).

http://creativecommons.org/licenses/by/4.0/

\begin{abstract}
Firstly, based on the data of international balance of payments, this paper analyzes the current situation of China's cross-border capital flow, and finds that China's cross-border capital flow can be divided into two stages due to its differentiated characteristics, and China's short-term capital outflow pressure is relatively high at this stage. Secondly, in order to better manage cross-border capital flows, this paper sorts out four types of management policies (namely, structural policies, macroeconomic policies, macro-prudential measures, and capital flow management measures), and analyzes the management effects of cross-border capital flows. Finally, the paper puts forward some policy suggestions. 1) The goal of China's macro-control is to maintain the balance of international payments, and the more foreign exchange reserves we do not pursue, the better. 2) The main objective of strengthening cross-border capital management is to buy time for necessary reforms and adjustments; 3) In the future, China should avoid excessive efforts in daily management of cross-border capital flows.
\end{abstract}

\section{Keywords}

Cross-Border Capital Flow, Management Measures, Management Effect

\section{Current Status of Cross-Border Capital Flows in China}

\subsection{Cross-Border Capital Flows Have Gone through Two Phases since the Financial Crisis}

Since the financial crisis, China's cross-border capital flows can be divided into two stages: in the five-year period from 2008 to 2013, China's cumulative current account surplus reached $\$ 1.40$ trillion and net capital inflows reached $\$ 1.11$ trillion, maintaining a "double surplus" in both the current account and capital ac- 
count; thus, the total balance of payments balance is also a surplus. The second stage is that from 2014 to the present, the total balance of payments has been deficit in five years and then returned to surplus, of which the capital account deficit has reached $\$ 0.66$ trillion and the current account surplus has also fallen to $\$ 0.99$ trillion. While the balance of payments remained positive, it was significantly reduced by the capital account deficit (see Figure 1).

In a specific analysis of the drivers of the large cross-border capital inflows in the first phase, developed economies used unconventional monetary policies (including ultra-low interest rates and quantitative easing) that led to excessive market liquidity in response to the financial crisis, and excess market liquidity began to flow to emerging economies. These monetary policies also contributed to the relative widening of the country's internal and external spreads, which in turn led to the beginning of the upward movement of the RMB exchange rate (di Giovann, 2005). Offshore capital markets began to target spreads for arbitrage, leading to a sharp increase in offshore capital inflows. Unlike the pre-2008 period, when balance-of-payments surpluses were driven by rapid economic growth, the risk of balance-of-payments volatility increased.

The reasons for cross-border capital outflows in the second phase mainly come from the following three aspects: First, the global economic landscape has been reshuffled after the 2008 subprime mortgage crisis in the United States, and the offshore capital market environment has changed dramatically. The US economy is gradually warming up in the real estate market; the level of inflation is gradually stabilizing, driven by the employment rate; the pace of recovery has greatly improved. Second, with the return of the dollar position, the conditions of global monetary finance have changed profoundly. The dollar exchange rate rallied again together with the tightening of spreads prompted the world's financial markets to start "long the dollar". Thus inducing the return of the strong dollar cycle, the dollar index also broke through the 100 mark accordingly. At the same time, emerging economy countries have experienced large and deep currency declines, offsetting the room for appreciation since the financial crisis.

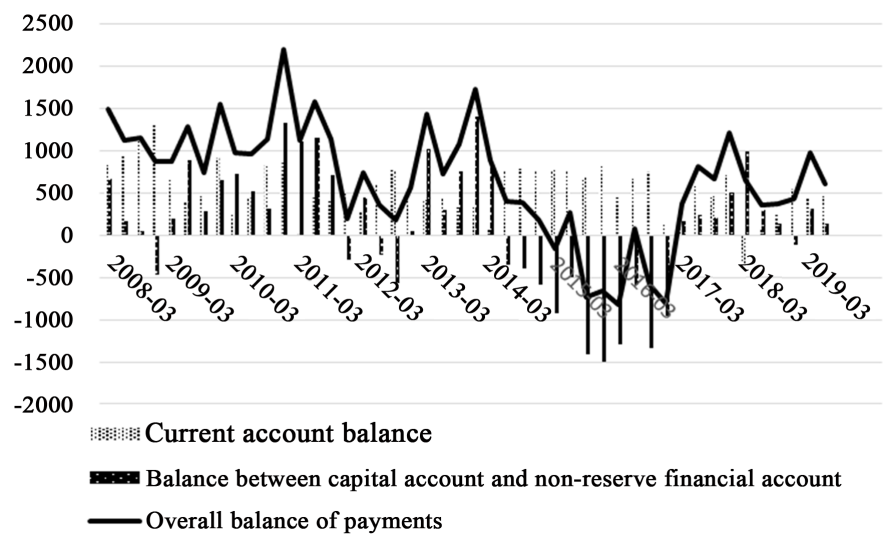

Figure 1. China's balance of payments, 2008-2018 (in billions of United States dollars). Data source: Wind. 
Third, as China's economy enters a new normal, the pressure of deep structural adjustment increases, and between 2010 and 2018, China's GDP growth rate fell from $10.6 \%$ to $6.6 \%$, the lowest annual rate since 1991 . In the manufacturing sector, the manufacturing economy fell; the Caixin China Manufacturing Purchasing Managers Index (PMI) most of the time is located below 50; exports: the export situation continues to be weak; the new export orders index for 2018 is 46.6; investment: the investment situation is worrying; in December 2018 investment growth is $5.9 \%$; the growth rate of 1.3 percentage points is lower than the same period last year.

\subsection{Increased Procyclical Short-Term Capital Outflow Pressures in Recent Years}

In the decade since the financial crisis, the issue of international capital flows has been a matter of great concern because our country has been plagued by frequent and large capital inflows and outflows.

According to the statistics, short-term capital flows (i.e. balance-of-payments calibre portfolio investment balance + other investment balance + financial derivatives balance + net errors and omissions) in 2008-2013 were somewhat pro-cyclical, but not significantly so. In all quarters of net short-term capital inflows and outflows, the two account for about half of the time. By examining the quarters of net short-term capital inflows, the authors find that the surplus of short-term capital flows is never higher than the underlying balance-of-payments surplus (i.e. current account balance of payments + direct investment balance) in the current period (see Figure 2). Over the six-year period, net short-term capital outflows were offset by net short-term capital outflows in the two years 2008 and 2012 , which amounted to $\$ 171.9$ billion over the period, or about 7.1 per cent of the underlying balance-of-payments surplus over the same period. It can be seen that the main source of the increase in foreign exchange reserve assets during this period was not hot money inflows but current account surplus and net cross-border direct investment inflows.

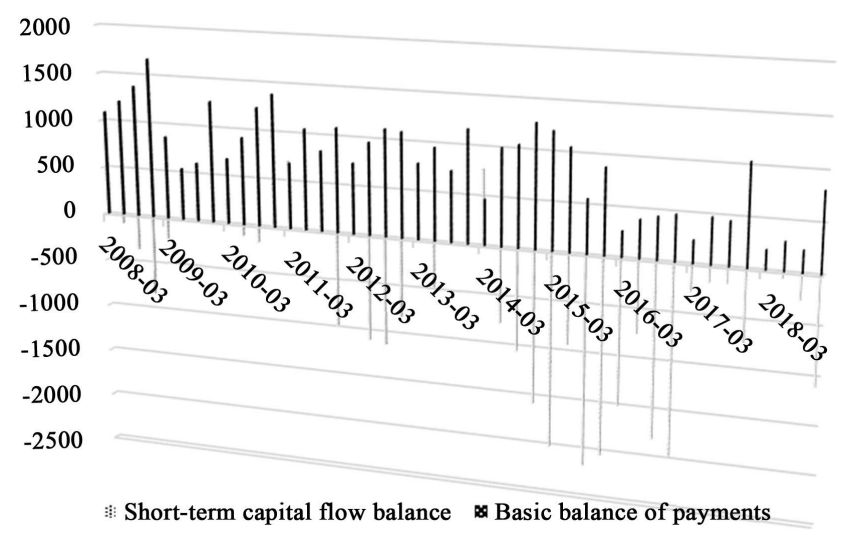

Figure 2. Short-term capital flows in China, 2008-2018 (in billions of United States dollars). Data source: Wind. 
In the second phase of cross-border capital flows (2014-2018), the main feature of short-term capital flows in our country is the flow in line with the economic cycle. With the exception of 2014 and the first quarter of 2108, the remaining quarters were all net outflows of short-term capital. Of all the quarters with net short-term capital outflows, 10 had net outflows higher than the underlying balance-of-payments surplus for the same period (see Figure 2). The cumulative amount of short-term net capital outflows during this period has approached $\$ 2$ trillion, which is 1.5 times the current period's basic balance of payments surplus, which is the main factor directly contributing to the decline in our foreign reserves. This is completely contrary to the recognition that our foreign exchange reserves have been growing steadily for a long time since 2014, when it was widely believed by capital institutions that balance-of-payments crises that other emerging markets had been coping with for a long time were less likely to occur in our country. However, between 2014 and 2018, the risk of reversing short-term capital flows to our country suddenly became greater.

\section{Policies for Managing Cross-Border Capital Flows}

\subsection{Four Types of Policies to Address Cross-Border Capital Flows}

From an international perspective, the IMF's approach to capital flow management has undergone a gradual shift from a negation of capital controls to a greater recognition of macroprudential management of cross-border capital flows. Before the Southeast Asian economic crisis in 1997, the IMF strongly promoted global capital account opening and "de-capitalization". After 1997, the IMF began to reflect on the rationality of its approach to cross-border capital flow management. Since 2000, the IMF has begun to recognize the rationality of cross-border capital flow management in emerging economies when necessary, and has proposed four main types of policies to address cross-border capital flows: structural policies, macroeconomic policies, macroprudential measures (MPMs) and capital flow management measures (CFMs) (see Table 1).

First, structural policies refer to policies to improve the quality of a country's economic development and strengthen the foundations for attracting long-term capital, mainly in terms of promoting openness to trade and investment, encouraging innovation, promoting fiscal reform, improving and strengthening the financial system and promoting inclusive growth (Alper et al., 2013). From a practical point of view, in 2018, the yuan depreciated $5.15 \%$ against the dollar, the possible reasons include: first, the current account surplus as a proportion of GDP decreased, from $1.41 \%$ to $0.36 \%$; second, the external debt dependence increased, up $4.5 \%$ from last year; third, foreign exchange reserves decreased, down 67.237 billion US dollars from the previous year; fourth, the industrial upgrading and transformation progressed slowly. Affecting cross-border capital flows by adjusting these aspects requires the use of structural policies that increase the potential productivity of the economy. 
Table 1. Four categories of policies for managing cross-border capital flows.

\begin{tabular}{|c|c|c|c|c|}
\hline & $\begin{array}{l}\text { Structural } \\
\text { policies }\end{array}$ & $\begin{array}{l}\text { Macroeconomic } \\
\text { policy }\end{array}$ & $\begin{array}{l}\text { Macro prudential } \\
\text { measures }\end{array}$ & $\begin{array}{c}\text { Capital flow } \\
\text { management measures }\end{array}$ \\
\hline Tool properties & $\begin{array}{l}\text { Long-term } \\
\text { measures }\end{array}$ & $\begin{array}{c}\text { Short and medium-term } \\
\text { measures }\end{array}$ & $\begin{array}{c}\text { Short and } \\
\text { medium-term measures }\end{array}$ & Short and medium-term measures \\
\hline $\begin{array}{l}\text { Implementation } \\
\text { objectives }\end{array}$ & $\begin{array}{l}\text { Enhancing economic } \\
\text { development potential }\end{array}$ & $\begin{array}{l}\text { Achieving macro } \\
\text { policy objectives }\end{array}$ & $\begin{array}{c}\text { Preventing } \\
\text { systemic risk }\end{array}$ & Direct management of capital flows \\
\hline $\begin{array}{l}\text { Implementation } \\
\text { context }\end{array}$ & $\begin{array}{l}\text { Countries to move } \\
\text { forward selectively } \\
\text { and continuously } \\
\text { according to their } \\
\text { development needs }\end{array}$ & $\begin{array}{c}\text { Preference for } \\
\text { macroeconomic } \\
\text { risks arising from } \\
\text { cross-border capital flows }\end{array}$ & $\begin{array}{c}\text { Preferential use } \\
\text { when cross-border } \\
\text { capital flows pose } \\
\text { financial stability risks }\end{array}$ & $\begin{array}{l}\text { Use when macroeconomic and } \\
\text { macroprudential policies are } \\
\text { not effective in addressing the } \\
\text { risks of cross-border capital flows }\end{array}$ \\
\hline Specific tools & $\begin{array}{l}\text { Industrial } \\
\text { policy, } \\
\text { micro policy }\end{array}$ & $\begin{array}{l}\text { Exchange rate } \\
\text { policy, reserve } \\
\text { policy, monetary } \\
\text { policy, fiscal } \\
\text { policy, etc. }\end{array}$ & $\begin{array}{l}\text { Countercyclical capital buffers, } \\
\text { loan-to-value ratios, } \\
\text { debt-to-income ratios, } \\
\text { limiting liquidity } \\
\text { mismatches, limiting } \\
\text { currency mismatches, etc. }\end{array}$ & $\begin{array}{l}\text { Restricting the borrowing of } \\
\text { foreign debt by domestic subjects, } \\
\text { restricting the flow of foreign capital } \\
\text { into the domestic securities market, } \\
\text { restricting the foreign currency } \\
\text { positions of banks, etc. }\end{array}$ \\
\hline
\end{tabular}

Second, macroeconomic policies affect domestic and foreign spreads and thus cross-border capital flows through policies such as monetary policy, fiscal policy, exchange rate policy, reserve policy and offsetting intervention. For example, by regulating interest rates through monetary policy, an instrument applied in the absence of economic overheating or rising asset prices. It is also possible to regulate supply and demand in the foreign exchange market through exchange rate policy, an instrument that applies when the currency is not overvalued relative to fundamentals (Brunnermeier et al., 2012). Or intervention in the foreign exchange market through a reserve policy, which is an instrument for intervening in the foreign exchange market to accumulate international reserves when they are insufficient. The accumulation of foreign exchange reserves also helps to limit excessive exchange rate fluctuations in the short term and mitigate the impact on the balance sheet. However, when foreign exchange reserves are already relatively high, intervention costs such as elimination costs and foreign asset valuation losses may exceed gains. In addition, large-scale interventions during periods of sustained capital inflows are likely to increase capital inflows, as this fuels expectations of further appreciation of the currency.

Again, Macro Prudential Measures (MPM) are prudential policies to address systemic risk. It focuses on macro, cross-sectoral, counter-cyclical and systemically important institutions. The policy is not implemented directly to control cross-border capital flows, but it also affects cross-border capital flows. MPM's main functions include enhancing the financial system's ability to cope with situation reversals, reducing the procyclicality of the financial sector's amplifying effect on economic volatility, and strengthening the regulation of systemically important financial institutions. Specific measures include countercyclical capital buffers, capital surcharge requirements, liquidity surcharge requirements, etc. (see Table 2 for details). 
Table 2. IMF lists Macro Prudential Measures (MPM).

\begin{tabular}{cc} 
Cyclical risk (cross-over) & $\begin{array}{c}\text { Structural risk } \\
\text { (cross-sector, cross-product, cross-agency) }\end{array}$ \\
\hline Countercyclical capital buffer (CCB) & $\begin{array}{c}\text { Systemically important institutional management } \\
\text { Systematic capital surcharge requirements }\end{array}$ \\
Taxation of non-core types of debt & Additional system liquidity requirements \\
Countercyclical risk weights & Tax on non-core types of debt \\
Periodic systemic flow addition & Higher capital requirements for transactions \\
Periodic repurchase valuation discount & not cleared through a central counterparty
\end{tabular}

Finally, capital flow management measures (CFMs) are measures that directly affect the aggregate or composition of capital flows and mainly refer to measures that restrict capital flows, both those that distinguish between residents and non-residents (capital controls) and those that do not distinguish between residents and non-residents (macroprudential management of cross-border capital flows), see Table 3 for details.

\subsection{Distinction between MPMs and CFMs}

First, MPM and CFMs are similar in function, but each has its own focus; MPM is considered by the OECD as the "foundation" for resisting external shocks and maintaining financial stability and should be used as a priority. Among them, one of the CFMs, Currency Based Measures (CBMs), serves as a macroprudential measure that directly affects cross-border capital flows and is a "fence" for mitigating external shocks, which can strengthen its role. Other CFMs, such as capital controls, are the "firewall" against external financial shocks and the last bastion of financial stability.

Second, there are cross-cutting components between the two financial precautionary instruments, MPM and CFMs, which are difficult to distinguish completely. If cross-border capital flows raise systemic risk and CFMs are effective in reducing systemic risk, then CFMs also have MPM properties. For example, if non-residents purchase real estate on a large scale to drive up house prices, the use of non-residents to lend to real estate that is different from that of residents is an MPM and also has the property of CFMs.

Third, in its consultations with countries, the IMF has classified CFMs as "appropriate" and "inappropriate". If CFMs continue to be used in the context of improving macroeconomic policies, they will be judged "inappropriate" by the IMF. While such a determination would have no direct consequences, it would damage the country's international image, and the IMF's determination of the "appropriateness" of a CFMs policy would take into account a variety of factors and the actual situation in the country. The IMF's judgement on these issues may differ between the IMF and the country concerned, and within the IMF as well; the IMF considers that CFMs are measures for "open" projects and 
Table 3. Cross-border capital flow management measures (CFMs) listed by the IMF.

\begin{tabular}{|c|c|c|}
\hline Management direction & Type of measure & Specific requirements \\
\hline \multirow{11}{*}{$\begin{array}{l}\text { Responding to } \\
\text { capital inflows }\end{array}$} & \multirow{4}{*}{ Restrictions } & Restrictions on residents borrowing from non-residents \\
\hline & & Restricting foreign exchange derivatives positions \\
\hline & & Restricting banks' foreign currency deposit and loan ratios \\
\hline & & Limiting the proportion of banks' short-term external debt \\
\hline & \multirow{3}{*}{ Taxation } & Taxation of funds invested in securities, margin deposits and derivatives \\
\hline & & Taxation of interest earned on treasury bills held by non-residents \\
\hline & & Taxation of non-deposit foreign currency denominated liabilities of banks \\
\hline & \multirow[t]{2}{*}{ Holding period requirements } & $\begin{array}{l}\text { Setting a minimum holding period for non-residents to invest in domestic } \\
\text { financial assets }\end{array}$ \\
\hline & & Borrowing by residents from non-residents is subject to a reserve \\
\hline & \multirow[t]{2}{*}{ Reserve requirements } & Foreign exchange deposits are subject to a reserve \\
\hline & & Foreign exchange derivatives transactions are subject to a reserve \\
\hline \multirow{19}{*}{$\begin{array}{l}\text { Responding to } \\
\text { capital outflows }\end{array}$} & \multirow{6}{*}{ Restrictions } & Restrictions on the holding of offshore assets by residents \\
\hline & & Restrictions on the withdrawal of foreign currency notes from banks in cash \\
\hline & & Restrictions on non-payable foreign exchange derivative transactions \\
\hline & & $\begin{array}{l}\text { Restrictions on the use of payment cards denominated in foreign } \\
\text { currency abroad }\end{array}$ \\
\hline & & Limiting the daily foreign exchange purchase position of banks \\
\hline & & $\begin{array}{l}\text { Restrictions on individuals' access to non-trade related international } \\
\text { non-resident financing in local currency }\end{array}$ \\
\hline & Taxation & $\begin{array}{l}\text { Tax on foreign exchange purchased by banks } \\
\text { Introduction of a new tax on transfer of earnings }\end{array}$ \\
\hline & \multirow{5}{*}{$\begin{array}{l}\text { Prohibition/licensing } \\
\text { requirements }\end{array}$} & Resident loans to non-residents are permitted or prohibited \\
\hline & & Early repayment of non-resident loans is permitted or prohibited \\
\hline & & Permission to transfer dividends abroad \\
\hline & & Conversion and transfer of foreign monetary assets subject to \\
\hline & & licensing or prohibition \\
\hline & Reserve requirements & For foreign exchange forward contracts and related derivative transactions \\
\hline & Compulsory repatriation claims & $\begin{array}{l}\text { Requiring residents to repatriate export earnings or investment income } \\
\text { released outside the country within a certain period of time }\end{array}$ \\
\hline & \multirow{3}{*}{ Holding period requirements } & Setting a minimum holding period for transfers of domestic \\
\hline & & financial assets by non-residents \\
\hline & & $\begin{array}{l}\text { Creation of a waiting period for gains on non-resident transfers of } \\
\text { domestic securities }\end{array}$ \\
\hline & \multirow[b]{2}{*}{ Others } & Overseas dividends, interest, payments need to be in foreign currency \\
\hline & & $\begin{array}{l}\text { No additional foreign exchange can be purchased for external payments } \\
\text { when own foreign exchange is available }\end{array}$ \\
\hline
\end{tabular}

can be used, but emphasizes that it is best not to repeat the opening of capital projects, and that it is best not to go back when capital projects have been opened, unless the other measures have failed. The logic is that a country can decide how fast or slow to "open up" according to the degree of financial stability, but once "open up", it should try to maintain policy stability and avoid the uncertainty and distortion of the market caused by going backwards. Therefore, it is better to implement liberalization cautiously than to go back when cross-border capital flows are volatile after excessive liberalization. 


\section{Effectiveness of Management of Cross-Border Capital Flows}

\subsection{Effectiveness of Inflow Direction Management}

Before the beginning of 2014, our country had to deal with the massive inflow of capital from abroad on the one hand, and curb the rapid appreciation of the yuan on the other (Kimball \& Xiao, 2006). The management of cross-border capital flows in China is a two-way balanced management of flows in and out, and the management of inflows is an expansion of inflows. Although this measure has had some effect, but still, it has not changed the status quo of the "double surplus" in the balance of payments, especially in the two years of 2011 and 2013 at the end of the renminbi appreciation round (see Figure 1), the main factor affecting the increase in foreign exchange reserve assets in the current period is that the size of net capital inflows exceeded the current account surplus. There are two reasons for this phenomenon: first, the long-term unilateral gradual appreciation of the RMB exchange rate, the RMB has gradually become the most favored currency among carry trade currencies, which is difficult to prevent in management; second, the balance of payments adjustment mechanism is too slow due to the adjustment of capital flow management norms of "loose in, strict out", resulting in the failure of balanced adjustment, "two-way balanced management of flows in and out" has little effect, which to a certain extent hinders the implementation of capital outflows against trade surpluses; third, the concern that excessive control and regulation of capital inflows will likely have an adverse impact on foreign trade and reasonable inflow of foreign capital, and management is tied.

\subsection{Effectiveness of Outflow Direction Management}

In general, managing outflows is more efficient. For example, in 2014, the balance of payments began to decline, in the fight against export evasion, import fraud and other measures to gradually promote, and further regulate the overseas investment behavior of domestic enterprises, domestic enterprises overseas investment M\&A behavior gradually returned to rational, the balance of payments to a surplus. The deficit between the capital account and non-reserve financial accounts decreased from a deficit of $\$ 58.323$ billion at the end of 2014 to a deficit of $\$ 12.481$ billion at the end of 2018 , and foreign exchange reserve assets reversed from a decrease of $\$ 448.7$ billion in 2017 to an increase of $\$ 93$ billion at the end of 2018 (see Figure 1). Adequate foreign exchange asset reserves effectively defused the reversal of capital flows and effectively maintained the country's financial security.

\section{Main Recommendations}

First of all, China's macro-control goal is to maintain the balance of payments, and clearly do not pursue foreign exchange reserves and the more the better. 
Our foreign exchange presence reached an all-time high of $\$ 3.99$ trillion in 2014, resulting in an unanticipated accumulation of foreign exchange reserves. The reason for this, in my view, is the unconventional monetary policies of the major economies, which have led to large inflows of foreign capital into emerging markets, including China. However, our country has always insisted on looking inward, actively looking for the causes from itself, and determined the general idea of "expanding domestic demand, adjusting structure, reducing surplus and promoting balance", rather than using other countries as "scapegoats" for their own economic imbalances. In the deepening of economic restructuring, industrial structure upgrading into the right track, at the same time, the trade environment has also changed, China's current account surplus and GDP ratio, during the decade from the 2008 peak of $9.1 \%$ to a rapid return to far less than $4 \%$ of the internationally recognized reasonable standards (see Figure 3). From the perspective of the long-term healthy development of China's economy, we should further reduce the degree of restriction on capital outflows and continue to insist on consolidating the balance of payments pattern of "current account surplus, capital account deficit" (Giordani et al., 2017). The "double surplus" can no longer adapt to the new international financial situation, and it is difficult to have a favourable impact on the independent balance of payments, and even more difficult to guarantee a clean float of the RMB exchange rate (i.e. a completely free float) (Wang \& $\mathrm{Ni}, 2007$ ).

Second, the main purpose of strengthening cross-border capital management is to buy time for the necessary reforms and adjustments. Whether "preventing inflows" or "controlling outflows", reliable price signals are needed to ensure the effectiveness of cross-border capital flow management. However, if we fail to effectively overcome our concerns about the floating exchange rate, which will lead to a long-term lack of marketization of the exchange rate, our country will cycle back and forth between the capital flow management policies of "preventing inflows" and "controlling outflows", an awkward situation that will, to a large extent, limit our active role in the process of economic globalization (Garber, 1998).

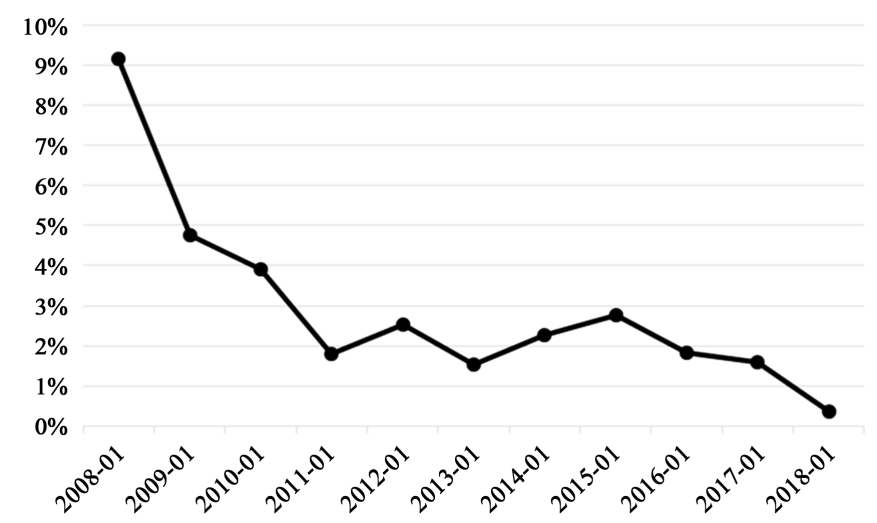

Figure 3. External economic balance of the country (China's current account surplus and GDP ratio). Data source: Wind. 
Finally, in the future, our country should avoid exerting too much force in the daily management of cross-border capital flows. We need to keep our promises, return to market mechanisms, adopt more market-friendly strategies and improve capital management efficiency. The foreign exchange market is changing rapidly; we not only need to make good plans based on scenario analysis and stress testing, but also to fundamentally improve the ability to respond to abnormal capital flows in a timely manner. The future regulatory framework for capital flows should include the following five aspects: first, the use of market-based exchange rate and interest rate instruments to reasonably regulate cross-border capital flows; second, compliance regulation based on negative lists; third, micro-prudential management of domestic and foreign currency consolidation; fourth, macro-prudential measures, including the Tobin tax; and fifth, the establishment of temporary capital control instruments.

\section{Conflicts of Interest}

The author declares no conflicts of interest regarding the publication of this paper.

\section{References}

Alper, K., Kara, H., \& Yörükoğlu, M. (2013). Alternative Tools to Manage Capital Flow Volatility. BIS Paper.

Brunnermeier, M., De Gregorio, J., Eichengreen, B. et al. (2012). Banks and Cross-Border Capital Flows: Policy Challenges and Regulatory Responses. Committee on International Economic Policy and Reform.

di Giovanni, J. (2005). What Drives Capital Flows? The Case of Cross-Border M\&A Activity and Financial Deepening. Journal of international Economics, 65, 127-149. https://doi.org/10.1016/j.jinteco.2003.11.007

Garber, P. M. (1998). Derivatives in International Capital Flows. National Bureau of Economic Research. https://doi.org/10.3386/w6623

Giordani, P. E., Ruta, M., Weisfeld, H. et al. (2017). Capital Flow Deflection. Journal of International Economics, 105, 102-118. https://doi.org/10.1016/j.jinteco.2016.12.007

Kimball, D., \& Xiao, F. (2006). Effectiveness and Effects of China's Capital Controls. In Conference: WTO, China, and the Asian Economies, IV, Economic Integration and Economic Development, University of International Business and Economics, June 2006, Beijing, 24-25.

Wang, B.-Y., \& Ni, N. (2007). Establishing an Emergency Mechanism of Cross-Border Capital Flow Risk. Financial Theory \& Practice, No. 9, 33-35. 